\title{
Lack of association between ACE I/D and AGTR1 A1166C gene polymorphisms and preeclampsia in Turkish pregnant women of Trakya region
}

\author{
Nevra Alkanli ${ }^{1}$, Tammam Sipahi ${ }^{1, ~}$, Tulay Okman Kilic ${ }^{2}$, Seralp Sener ${ }^{1}$ \\ ${ }^{1}$ Department of Biophysics, Faculty of Medicine, Trakya University, Edirne, Turkey \\ ${ }^{2}$ Department of Obstetrics and Gynecology, Faculty of Medicine, Trakya University, Edirne, Turkey
}

\section{Email address:}

tammam@trakya.edu.tr (T. Sipahi)

\section{To cite this article:}

Nevra Alkanli, Tammam Sipahi, Tulay Okman Kilic, Seralp Sener. Lack of Association between ACE I/D and AGTR1 A1166C Gene Polymorphisms and Preeclampsia in Turkish Pregnant Women of Trakya Region. Journal of Gynecology and Obstetrics.

Vol. 2, No. 4, 2014, pp. 49-53. doi: 10.11648/j.jgo.20140204.11

\begin{abstract}
The aim of this study was to investigate the distribution of Angiotensin Converting Enzyme Insertion/Deletion (ACE I/D) and the distribution of Angiotensin II Type 1 Receptor A1166C (AGTR1 A1166C) gene polymorphisms in preeclamptic pregnant women comparing to control pregnant women in Turkish subjects of Trakya Region. We aimed to determine whether these polymorphisms are genetic risk factor for preeclampsia. The study included 75 preeclamptic pregnant women and 75 control pregnant women, which were categorized according to The World Health Organization Detecting Pre-eclampsia: A Practical Guide. The ACE I/D gene polymorphism was investigated using Polymerase Chain Reaction (PCR) method. The AGTR1 A1166C gene polymorphism was identified using PCR and followed by Restriction Fragment Length Polymorphism (RFLP) methods. The ACE I/D genotype distribution in preeclamptic pregnant women $\mathrm{DD}=36.0 \%, \mathrm{ID}=44.0 \%$ and $\mathrm{II}=20.0 \%$ did not significantly differ from those in control pregnant women $\mathrm{DD}=38.7 \%$, $\mathrm{ID}=50.7 \%$ and $\mathrm{II}=10.6 \%(\mathrm{P}=0.279)$. The AGTR1 A1166C genotype distribution in preeclamptic pregnant women $\mathrm{AA}=57.3 \%, \mathrm{AC}=33.4 \%$ and $\mathrm{CC}=9.3 \%$ also did not significantly differ from those in control pregnant women $\mathrm{AA}=70.7$, $\mathrm{AC}=24.0 \%$ and $\mathrm{CC}=5.3 \% \quad(\mathrm{P}=0.223)$. This case-control study show that $\mathrm{ACE} \mathrm{I} / \mathrm{D}$ and AGTR1 A1166C gene polymorphisms are not genetic risk factors for preeclampsia in this population in Turkish pregnant women of Trakya Region.
\end{abstract}

Keywords: Preeclampsia, ACE I/D Gene Polymorphism, AGTR1 A1166C Gene Polymorphism, PCR, RFLP

\section{Introduction}

Preeclampsia (PE), characterized by the development of hypertension and proteinuria after 20 weeks of gestation, is a common and serious disease that complicates in $5 \%$ to $8 \%$ of human pregnancies and remains a leading cause of maternal mortality and fetal morbidity (1). Abnormalities in the maternal immune system and lack of gestational immune tolerance appear to play major roles in PE. Furthermore, several pathophysiological mechanisms have been implicated in the development of PE include endothelial dysfunction, inflammatory pathway, oxidative stress, activation of thrombosis and the compensatory and delicate changes of Renin Angiotensin Aldosterone System (RAAS) during normal pregnancy $(1,2)$.

The Pathogenesis of PE remains obscure, but it has been considered to be a multifactorial and multisystemic disorder, especially with a genetic predisposition (3). Several features of the RAAS in PE differ from that in normal pregnant state. RAAS could be the foundation for the genetics of $\mathrm{PE}$ and the various gene polymorphisms of RAAS seem most likely related to the development of PE disease (1-3).

RAAS components play a central role in the regulation of blood pressure, sodium metabolism and renal hemodynamics. RAAS comprises of the Angiotensinogen (AGT), Renin, Angiotensin I (ANG I), Angiotensin Converting Enzyme (ACE), Angiotensin II (ANG II), and Angiotensin II Coupled Receptors which are members of the $\mathrm{G}$ protein-coupled receptor superfamily $(4,5)$. Also agonistic antibodies against AGTR1 have been identified in pregnant women with PE (6).

ACE, a peptidyl carboxypeptidase is an important 
protease enzyme of the RAAS that regulates blood pressure by catalyzing the conversion of ANG I into ANG II (7). ANG II is a potent vazoconstrictive molecule that plays a key role in modulating vascular tone. ANG II exerts its effects by binding to ANG II Coupled Receptors. Most of the known effects of ANG II can be attributed to the AGTR1 (4). AGTR1 mediates its action by association with $G$ proteins that activate a phosphatidylinositol-calcium second messenger system which implicated in PE, followed by vazoconstriction, hypertrophy, or catecholamine liberation at sympathetic nerve endings $(4,5)$.

The ACE gene maps on chromosome 17 (17q23.3), spans $21 \mathrm{~kb}$, and comprises of 26 exons and 25 introns. The ACE $\mathrm{I} / \mathrm{D}$ gene polymorphism is due to the insertion or deletion of an alu short interspersed sequence, various base sequences dispersed in human, located on intron 16 (7).

The human AGTR1 gene is located on chromosome 3 (3q21-q25) and comprises of 5 exons and 4 introns. The AGTR1 A1166C gene polymorphism has been described in which there is either an Adenine (A) or a Cytosine $(\mathrm{C})$ base in position 1166 in the 3' untranslated region of the gene (8).

Several studies of RAAS components, responsible for high blood pressure, showed that ACE I/D and AGTR1 A1166C gene polymorphisms were associated with increased risk for hypertension $(9,10)$. On the other hand, there was no relationship between ACE I/D and/or AGTR1 A1166C gene polymorphisms and hypertension in the other studies $(11,12)$. In PE, evidence is accumulating that ACE I/D and AGTR1 A1166C gene polymorphisms are also associated with increased risk of PE disease $(13,14)$. In addition, various genetic and environmental risk factors have been considered to contribute in increasing the effects of these polymorphisms such as geographic, socioeconomic, and racial features. This prompted us initiating to examine the relationship between development of PE disease and gene polymorphisms of ACE and AGTR1 in Turkish pregnant women of Trakya Region.

\section{Materials and Methods}

The study included a total of 150 Turkish women containing 75 preeclamptic pregnant women which were categorized according to The World Health Organization Detecting Pre-eclampsia: A Practical Guide and 75 control pregnant women. The definition used for PE is based on high blood pressure and proteinuria. High blood pressure: Two separate readings taken at least six hours apart of 140 $\mathrm{mmHg}$ or more in systolic and/or $90 \mathrm{mmHg}$ or more in diastolic blood pressure. Proteinuria: $300 \mathrm{mg}$ of protein in a 24 hour urine sample after 20 weeks of pregnancy. The control pregnant women group among eligible subjects who were not affected by $\mathrm{PE}$ in the pregnancy progressing to $>20$ weeks gestation. Both of the preeclamptic and the control pregnant women were from Edirne or its surrounding areas with comparable socioeconomic cultural backgrounds. All participants gave informed consent that was approved by the local ethics committee.

\subsection{DNA Isolation}

DNA was isolated from peripheral blood, containing EDTA as an anticoagulant, by eZNA blood DNA kits (BOGA, Istanbul, Turkey). DNA purity and quality were assessed by absorbance values in spectrophotometer. The ratio of Optical Density (OD) at $260 \mathrm{~nm}$ to OD at $280 \mathrm{~nm}$ was found about 1.8 for all samples. DNA bands were observed by 0.8 agarose gel electrophoresis (Figure 1).

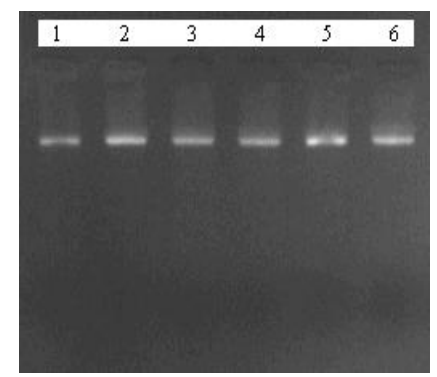

Figure 1. Ethidium bromide-stained $0.8 \%$ agarose gel of representative DNA samples.

\subsection{Genotyping of ACE I/D Gene Polymorphism}

To determine the ACE I/D gene polymorphism of the preeclamptic and the control groups, a genomic DNA fragments on intron 16 of the ACE gene was amplified by PCR in a $15 \mu \mathrm{l}$ PCR reaction mixture containing $100 \mathrm{ng}$ of DNA, dNTP (0.2 mM of each), upstream and downstream primers (300 pmol), 1XTaq Buffer $(75 \mathrm{mM}$ Tris- $\mathrm{HCl} \mathrm{pH}$ 8.8, $20 \mathrm{mM}\left(\mathrm{NH}_{4}\right)_{2} \mathrm{SO}_{4}, 0.01 \%$ Tween 20$), 2.5 \mathrm{mM} \mathrm{MgCl}$ and $0.75 \mathrm{U}$ of Taq DNA polymerase (Fermentas Life Sciences).

Upstream primer was:

5'-CTGGAGACCACTCCCATCCTTTCT-3'

Downstream primer was:

5'-GATGTGGCCATCACATTCGTCAGAT-3'

Amplification were performed with 5 minute of denaturation at $94^{\circ} \mathrm{C}$, followed by 30 cycles with denaturation for 1 minute at $94^{\circ} \mathrm{C}$, annealing for 1 minute at $58^{\circ} \mathrm{C}$, and extension for 1 minute at $72^{\circ} \mathrm{C}$, followed by 7 minute of extension at $72^{\circ} \mathrm{C}(15,16)$. The PCR products of two alleles of $490 \mathrm{bp}$ and $190 \mathrm{bp}$ were electrophoresed in $2 \%$ agarose gels, and visualized under ultraviolet (UV) light by ethidium bromide straining (Figure 2).

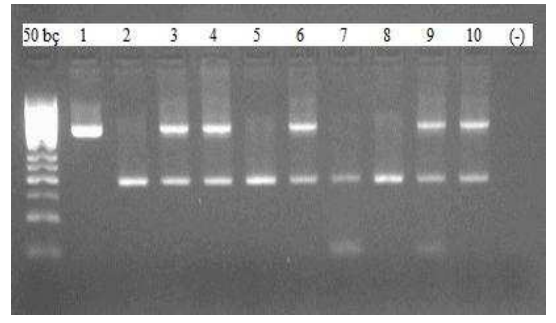

Figure 2. Ethidium bromide-stained 2\% agarose gel of representative $P C R$ products of ACE I/D gene polymorphism shows the DD genotype (190 bp, lane 2, 5, 7 and 8), the ID genotype (190 bp and $490 \mathrm{bp}$, lane 3, 4, 6, 9 and 10) and the II genotype (490 bp, lane 1), lane $50 \mathrm{bp}$ is a size marker (GeneRuler 50 bp DNA Ladder), and lane (-) is a negatif control. 


\subsection{Genotyping of AGTR1 A1166C Gene Polymorphism}

AGTR1 A1166C gene polymorphism was identified with PCR and followed by RFLP with the restriction enzyme HaeIII. 25 $\mu$ l PCR reaction mixture containing $200 \mathrm{ng}$, dNTP (0.2 mM of each), 500 pmol of each primer, 1XTaq Buffer (75 $\mathrm{mM}$ Tris- $\mathrm{HCl} \mathrm{pH} 8.8,20 \mathrm{mM}\left(\mathrm{NH}_{4}\right)_{2} \mathrm{SO}_{4}, 0.01 \%$ Tween 20 ), $1.5 \mathrm{mM} \mathrm{MgCl}_{2}$ and $1.25 \mathrm{U}$ of Taq DNA polymerase.

Upstream primer was:

\section{5'-GCAGCACTTCACTACCAAATGGGC-3'}

Downstream primer was:

\section{5'-CAGGACAAAAGCAGGCTAGGGAGA-3'}

Amplification were performed with denaturation for 5 minute at $94^{\circ} \mathrm{C}$, followed by 35 cycles with denaturation for 1 minute at $94^{\circ} \mathrm{C}$, annealing for 1 minute at $55^{\circ} \mathrm{C}$, and extension for 1 minute at $72^{\circ} \mathrm{C}$, followed by 7 minute of extension at $72^{\circ} \mathrm{C}$ (16). The PCR products were electrophoresed in $2 \%$ agarose gels, and visualized under UV light by ethidium bromide staining. $5 \mu \mathrm{l}$ of PCR product were digested with $5 \mathrm{U}$ of the restriction enzyme HaeIII in 1XM Buffer (10 mM Tris- $\mathrm{HCl} \mathrm{pH} 7.5,10 \mathrm{mM}$ $\mathrm{MgCl}_{2}, 1 \mathrm{mM}$ Dithiothreitol and $50 \mathrm{mM} \mathrm{NaCl}$ ) for 3 hours at $37^{\circ} \mathrm{C}$. When mutant allele (Cytosine), digested with HaeIII that yield two fragments $231 \mathrm{bp}$ and $24 \mathrm{bp}$, whereas a wild allele (Adenine) at nucleotide position 1166, had no cutting site for HaeIII, so that the $255 \mathrm{bp}$ PCR product was not cleaved into $231 \mathrm{bp}$ and $24 \mathrm{bp}$ fragments (16). The restriction digest products were visualized by UV light after electrophoresis on a $2.5 \%$ agarose gel and ethidium bromide staining (Figure 3).

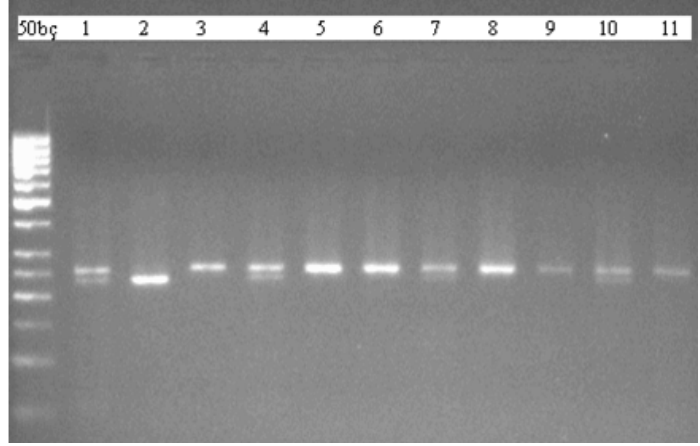

Figure 3. Ethidium bromide-stained $2.5 \%$ agarose gel of representative PCR digested products of AGTR1 A1166C gene polymorphism shows the $A A$ genotype (255 bp , lane 3, 5, 6, 8, 9, and 11), the AC genotype (255 bp. $231 \mathrm{bp}$ and $24 \mathrm{bp}$ (not detectable in agarose gel) lane 1, 4, 7, and 10) and the CC genotype (231 bp and 24 bp lane 2); lane 50 bp is a size marker.

\subsection{Statistical Analyses}

All statistical analyses were performed with the SPSS 15.0 software and STATA program, version 8. Genotype distribution of ACE I/D and AGTR1 A1166C of preeclamptic pregnant patients and control pregnant groups were evaluted by Chi-square test $(\chi 2$ test). Maternal age, gestational age, number of pregnancy, Body Mass Index (BMI), Systolic Blood Pressure (SBP) and Diastolic Blood Pressure (DBP) were examined by $\chi^{2}$ test or an independent student's $t$-test. The all values are represented as mean \pm Standard Deviation (SD). Significance was defined as $\mathrm{p}<0.05$.

\section{Results}

The maternal age, the gestational age, the number of pregnancy and other characteristics such as BMI, SBP and DBP of 75 pregnant women with $\mathrm{PE}$ and 75 pregnant controls are presented in Table 1. No significant differences were detected between preeclamptic pregnant and control pregnant groups for the maternal age, the gestational age and the number of pregnancy $(p>0.05)$. On the other hand, BMI, SBP and DBP as expected were significantly differed between the case-control groups $(p<0.05)$.

Table 1. The clinical characreristics of preeclamptic and control groups.

\begin{tabular}{llll}
\hline & $\begin{array}{l}\text { Preeclamptic } \\
\text { Group }(\mathbf{n = 7 5})\end{array}$ & $\begin{array}{l}\text { Control } \\
\text { Group }(\mathbf{n = 7 5})\end{array}$ & $\boldsymbol{p}$ \\
\hline Maternal Age (Years) & $27.87 \pm 6.44$ & $27.39 \pm 6.87$ & $\mathrm{NS}$ \\
Gestational Age (Weeks) & $36.5 \pm 3.6$ & $34.5 \pm 4.0$ & $\mathrm{NS}$ \\
Number of Pregnancy & $1.56 \pm 0.93$ & $1.72 \pm 1.20$ & $\mathrm{NS}$ \\
BMI $\left(\mathrm{kg} / \mathrm{m}^{2}\right)$ & $26.99 \pm 5.59$ & $23.83 \pm 3.38$ & 0.001 \\
SBP $(\mathrm{mmHg})$ & $156.67 \pm 14.08$ & $114.80 \pm 5.03$ & 0.001 \\
DBP $(\mathrm{mmHg})$ & $100.80 \pm 11.83$ & $73.33 \pm 4.75$ & 0.001 \\
\hline
\end{tabular}

$\mathrm{n}$; number of sample

$p$; values of significance with difference of each group, NS; not significant BMI; body mass index

SBP; systolic blood pressure

DBP; diastolic blood pressure

Genotype frequencies for the ACE I/D gene polymorphism is presented in Table 2. The overall frequencies of the genotypes DD, ID and II in preeclamptic pregnant group were $27(36.0 \%), 33(44.0 \%)$ and 15 $(20.0 \%)$ were not significantly differ from genotype frequencies in control pregnant group $29(38.7 \%), 38$ $(50.7 \%)$ and $8(10.6 \%)(p=0.279)$.

Table 2. Genotype frequencies for the ACE gene of PE and control groups.

\begin{tabular}{lllll}
\hline \multirow{2}{*}{ GENOTYPE } & GROUP & & \multirow{2}{*}{ TOTAL } & $\boldsymbol{P}$ \\
\cline { 2 - 3 } & PATIENT & CONTROL & & \\
\hline DD & $27(\% 36.0)$ & $29(\% 38.7)$ & $56(\% 37.3)$ & \\
ID & $33(\% 44.0)$ & $38(\% 50.7)$ & $71(\% 47.3)$ & \multirow{2}{*}{0.279} \\
II & $15(\% 20.0)$ & $8(\% 10.6)$ & $23(\% 15.3)$ & \\
TOTAL & $75(\% 100.0)$ & $75(\% 100.0)$ & $\begin{array}{l}150 \\
(\% 100.0)\end{array}$ & \\
\hline
\end{tabular}

DD; Deletion-Deletion, ID; Insertion-Deletion, II; Insertion-Insertion Statistical analysis was performed by using Chi-square test

Genotype frequencies for the AGTR1 A1166C gene polymorphism is presented in Table 3. AGTR1 A1166C genotypes AA, AC and $\mathrm{CC}$ in preeclamptic pregnant group were $43(57.3 \%), 25(33.4 \%)$ and $7(9.3 \%)$ respectively did not differ from genotype distribution in control pregnant group $53(70.7 \%), 18(24.0 \%)$ and $4(5.3 \%) \quad(p=0.223)$.

Our findings, in this case-control study populating, 
indicate that the ACE I/D and the AGTR1 A1166C gene polymorphisms were not genetic risk factors for PE in this population in Turkish pregnant women of Trakya Region.

Table 3. Genotype frequencies for the ATIR (A1166C) polymorphism of $P E$ and control groups.

\begin{tabular}{lllll}
\cline { 1 - 2 } A1166C & GROUP & & \multirow{2}{*}{ TOTAL } & P \\
\cline { 1 - 3 } GENOTYPE & PATIENT & CONTROL & & \\
\cline { 1 - 3 } AA & $43(\% 57.3)$ & $53(\% 70.7)$ & $96(\% 64.0)$ & \\
AC & $25(\% 33.4)$ & $18(\% 24.0)$ & $43(\% 28.7)$ & \multirow{2}{*}{0.223} \\
CC & $7(\% 9.3)$ & $4(\% 5.3)$ & $11(\% 7.3)$ & \\
TOTAL & $75(\% 100.0)$ & $75(\%$ & $150(\%$ & \\
\cline { 1 - 3 } & & &
\end{tabular}

AA; Adenine-Adenine, AC; Adenine-Cytosine, CC; Cytosine-Cytosine Statistical analysis was performed by using Chi-square test

\section{Discussion}

PE caused by secretion of inflammatory mediators from the placenta which finally affects the vascular endothelium. ANG II which has a critical role in increasing the blood pressure, has a serious role in producing an inflammatory response that appears to be involved in the pathogenesis of pregnancy (2). Elevation of the blood pressure is the most visible sign of the disease. Several studies identified various candidate genes involved in high blood pressure of pregnancy. Special attention on genes of the RAAS as AGT, ACE and AGTR1 which play key roles in blood pressure regulation and electrolyte balance $(2,9,10,17)$.

Many researchers investigated the relationship of PE and the common gene polymorphisms of the RAAS. I/D gene polymorphism of intron 16 of the ACE gene on chromosome 17 and A1166C gene polymorphism in the 3'untranslated region at nucleotide 1166 of the AGTR1 gene on chromosome $3(13,14)$ are the most important gene polymorphisms.

The frequency of the ACE I/D and the AGTR1 A1166C genotypes and their possible associations with the risk of $\mathrm{PE}$ have been investigated in different populations. Studies of the association of the ACE I/D and the AGTR1 A1166C gene polymorphisms with PE reported both positive $(13,14)$ and negative $(13,18)$ results. In Korean and Colombian populations, the ACE I/D polymorphism $(19,20)$ was not associated with the pathogenesis of PE. Also, in Greek and South African Black women $(21,22)$ neither ACE I/D nor AGTR1 A1166C variants were independently and directly associated with the risk of PE. In contrast, there are studies indicating that ACE I/D gene polymorphism might have a role in complications of pregnancy, including PE. In studies from South Eastern Iran (13) and Turkey (23) the presence of D allele of ACE was associated with increased risk of PE. In Northern India (24) of ACE I/D gene polymorphism appears to predispose to severe PE but not nonsevere PE. The study by Uma et al. suggested an association between the DD genotype of the ACE gene and early-onset but not later-onset PE (25). Furthermore, in a meta-analysis by Chen et al. (26) including 30 case-control studies the DD genotype of ACE was significantly associated with increased risk of pregnancy hypertensive disorders, especially among Asian and Caucasians. In Korean women the frequency of the DD genotype in patients with PE was about 2.5 times higher compared to general population and normotensive women during pregnancy (27). However, there were other studies showing that PE disease could be associated with I allele of the ACE gene (28).

Associations between AGTR1 A1166C gene polymorphism and $\mathrm{PE}$ have been investigated in the ethnicity meta-analysis, the results in Asians suggested that the $\mathrm{C}$ allele and the $\mathrm{AC} / \mathrm{CC}$ genotypes were associated with risk of pregnancy hypertensive disorders (14). However, many investigators found no association between the AGTR1 A1166C gene polymorphism and PE, neither in the Iran, Afro-Caribbean or Caucasian nor in Asian women populations $(13,29)$. Similar findings have been reported previously in meta-analysis findings which did not support AGTR1 A1166C as a susceptibility locus for development of PE disease (30).

In our study, ACE I/D genotype distribution DD, ID and II in preeclamptic pregnant group were 27 (36.0\%), 33 (44.0\%) and $15(20.0 \%)$ did not differ from control pregnant group 29 (38.7\%), $38(50.7 \%)$ and 8 (10.6\%). For AT1R (A1166C) genotype distribution $\mathrm{AA}, \mathrm{AC}$ and $\mathrm{CC}$ in preeclamptic pregnant group 43 (57.3\%), 25 (33.4\%) and 7 (9.3\%) did not also differ from control pregnant group $53(70.7 \%), 18$ $(24.0 \%)$ and $4(5.3 \%)$. Our results show that ACE I/D and AT1R (A1166C) gene polymorphisms were not genetic risk factors for PE in this population of Turkish pregnant women of Trakya region. However, in the preeclamptic pregnant group compared to control pregnant group there was a higher proportion of the AGTR1 CC genotype.

\section{References}

[1] Judi A Turner. Diagnosis and management of pre-eclampsia: an update. International Journal of Women's Health. 2010; (2): $327-337$.

[2] Jie Yang, Jianyu Shang, Suli Zhang, Hao Li and Huirong Liu. The role of the renin-angiotensin-aldosterone system in preeclampsia: genetic polymorphisms andmicroRNA. Journal of Molecular Endocrinology 2013; (50): 53-66.

[3] Paula J. Williams, Fiona Broughton Pipkin. The genetic of pre-eclampsia and other hypertensive disorders of pregnancy. Best Practice \& Research Clinical Obstetrics and Gynaecology. 2011; (25): 405-417.

[4] Christiane Ruster and Gunter Wolf. Renin-AngiotensinAldosterone System and Progression of Renal Disease. Journal of the American Society of Nephrology. 2006; (17): 2985-2991.

[5] Guo Deng Fu, Yu Lin Sun, Pavel Hamet, Tadashi Inagami. The angiotensin II type 1 receptor and receptor-associated proteins. Cell Research. (2001); 11 (3): 165-180.

[6] Thway TM, Shlykov SG, Day MC, Sanborn BM, Gilstrap LC III, Xia Y, Kellems RE. Antibodies from preeclamptic 
patients stimulate increased intracellular $\mathrm{Ca}^{2+}$ mobilization through angiotensin receptor activation. Circulation. 2004; 110 (12): 1612-1619.

[7] F. A. Sayed-Tabatabaei, B. A. Oostra, A. Isaacs, C. M. van Duijn, and J. C. M. Witteman. ACE polymorphisms. Circulation Research. 2006; 98 (9): 1123-1133.

[8] Bonnardeaux A, Davies E, Jeunemaitre X, Fery I, Charru A, Clauser E, et al. Angiotensin II type 1 receptor gene polymorphisms in human essential hypertension. Hypertension. 1994; 24: 63-69.

[9] Zarouk WA, Hussein IR, Esmaeil NN, Raslan HM, Reheim HAA, Moguib O, Emara NA, Aly AA, Hamed M. Association of angiotensin converting enzyme gene (I/D) polymorphism with hypertension and type 2 diabetes. Bratislava Medical Journal. 2012; 113 (1): 14-18.

[10] Bonnardeaux A, Davies E, Jeunemaitre X, Fery I, Charru A, Clauser E, Tiret L, Cambien F, Corvol P. Soubrier F. Angiotensin II type 1 receptor gene polymorphism in human essential hypertension. Hypertens. 1994;/24:/63-9.

[11] Badaruddoza and Neha Sudhir. No Evidence for Association Between ACE Gene Insertion (I)/ Deletion (D) Polymorphism and Hypertension in North Indian Punjabi Population. Int J Hum Genet. 2012; 12 (3): 179-185.

[12] Mary Esien Kooffreh, Chiaka Ijeoma Anumudu, Roseline Duke, Elza Cletus Okpako and P. Lava Kumar. Angiotensin II type 1 receptor $\mathrm{A} 1166 \mathrm{C}$ gene polymorphism and essential hypertension in Calabar and Uyo cities, Nigeria. Indian J Hum Genet. 2013; 19 (2): 213-218.

[13] Salimi S, Mokhtari M, Yaghmaei M, et al. Association of angiotensin-converting enzyme intron 16 insertion/deletion and angiotensin II type 1 receptor $\mathrm{A} 1166 \mathrm{C}$ gene polymorphisms with preeclampsia in South East of Iran. J Biomed Biotechnol 2011; 2011: 941515.

[14] Lu Shun Zhang, Han Qi Yang, Hao Jie Qin and Kui Zhang. Angiotensin II type I receptor A1166C polymorphism increases the risk of pregnancy hypertensive disorders: Evidence from a meta-analysis. Journal of the ReninAngiotensin- Aldosterone System. 2012; DOI: $10.1177 / 1470320312467556$.

[15] T.Sipahi, M.Budak, S.Şen, A.Ay, S.Şener, “Association Between ACE Gene Insertion (I) / Deletion (D) Polymorphism and Primary Hypertension in Turkish Patients of Trakya Region", Biotechnol. \& Biotechnol. Eq., 2006; 20 (2): 104-108.

[16] T.Sipahi, B.Guldiken, S.Guldiken, S.Ustundag, N.Turgut, M.Budak, S.Cakina, H.Ozkan, S.Sener. The Association of Gene Polymorphisms of the Angiotensin-Converting Enzyme and Angiotensin II Receptor Type 1 with Ischemic Stroke in Turkish subjects of Trakya Region. Trakya Univ. Tip Fak. Derg., 2009; 1-8.

[17] A.A.Basak, T.Sipahi, S.Ustundag, Z.Ozgen, M.Budak, S.Sen, S.Sener. Association of angiotensinogen T174M and M235T gene variants with development of hypertension in Turkish subjects of Trakya region. Biotechnol. \& Biotechnol. Eq. 2008; 22 (4): 984-989.

[18] Hassan A. Alsokary, Mostafa A. Kamel, Sameh S. Sadek, Nermine H. Zakaria, Iman A. Abdel Fatah. Study of angiotensin converting enzyme and genotype among Egyptian preeclampsia patients. American Journal of
Molecular Biology, 2014, (4): 26-36.

[19] Kim YJ, Park MH, Park HS, et al. Associations of polymorphisms of the angiotensinogen M235 polymorphism and angiotensin-converting-enzyme intron 16 insertion/deletion polymorphism with preeclampsia in Korean women. Eur J Obstet Gyn R B 2004; 116: 48-53.

[20] Serrano NC, Diaz LA, Paez MC, Mesa CM, Cifuentes R, Monterrosa A, Gonzalez A, Smeeth L, Hingorani AD, Casas JP. Angiotensin-converting enzyme I/D polymorphism and preeclampsia risk: evidence of small-study bias. PLoS Medicine. 2006; 3 (12): 2304-2316.

[21] Bouba I, Makrydimas G, Kalaitzidis R, Lolis DE, Siamopoulos KC, Georgiou I. Interaction between the polymorphisms of the renin-angiotensin system in preeclampsia. European Journal of Obstetrics \& Gynecology and Reproductive Biology 2003; 110: 8-11.

[22] Roberts CB, Rom L, Moodley J, et al. Hypertension-related gene polymorphisms in pre-eclampsia, eclampsia and gestational hypertension in Black South African women. J Hypertens 2004; 22 (5): 945-948.

[23] Ceyhun Bereketoglu, Mulkiye Kasap and Ayfer Pazarbasi. Studies on Angiotensin-Converting Enzyme Insertion/Deletion Polymorphism and Genotype Distributions in Turkish Preeclampsia Patients. Journal of Pregnancy. 2012; DOI: 10.1155/2012/108206.

[24] Aggarwal S, Dimri N, Tandon I, et al. Preeclampsia in North Indian women: the contribution of genetic polymorphisms. J Obstet Gynaecol Res 2011; 37: 1335-1341.

[25] Uma R, Forsyth SJ, Struthers AD, Fraser CG, Godfrey V, Murphy DJ. Polymorphisms of the angiotensin converting enzyme gene in early-onset and late-onset pre-eclampsia. J Matern Fetal Neonatal Med 2010; 23: 874-879.

[26] Chen Z, Xu F, Wei Y, Liu F, Qi H. Angiotensin converting enzyme insertion/deletion polymorphism and risk of pregnancy hypertensive disorders: a meta-analysis. Journal of the Renin-Angiotensin-Aldosterone System. 2012; 13 (1): 184-195.

[27] Hyunah Choi, Ja Young Kang, Hong Sun Yoon, Seung Suk Han, Chang Sun Whang, In Gul Moon, Hyun-Ho Shin, Jeong Bae Park. Association of Angiotensin-Converting Enzyme and Angiotensinogen Gene Polymorphisms with Preeclampsia. J Korean Med Sci. 2004; 19: 253-257.

[28] Roh CR, Kim DK, Yoon BK, Yang SH, Chung JH, Bae DS, Lee JH. A common genetic variant of the angiotensin converting enzyme (ACE) gene and pregnancy induced hypertensive disorders. Korean J Obstet Gynecol 1997; 40: 1189-99.

[29] Syed Ali Akbar, Nuzhat P. Khawaja, Paul R. Brown, Rakhshanda Tayyeb, Jacqueline Bamfo1\&Kypros H. Nicolaides. Angiotensin II type 1 and 2 receptors gene polymorphisms in pre-eclampsia and normal pregnancy in three different populations. Acta obstetricia et gynecologica Scandinavica. 2009; 88 (5): 606-611.

[30] Linlu Zhao, Andrew T. Dewan, and Michael B. Bracken. Association of maternal AGTR1 polymorphisms and preeclampsia: a systematic review and meta-analysis. J Matern Fetal Neonatal Med. 2012; 25 (12): 2676-2680. 